Tropical Journal of Pharmaceutical Research February 2019; 18 (2): 321-325

ISSN: $1596-5996$ (print); 1596-9827 (electronic)

(C) Pharmacotherapy Group, Faculty of Pharmacy, University of Benin, Benin City, 300001 Nigeria.

\title{
Evaluation of cytotoxic and wound healing effect of DMEM extracts of Turkish propolis in MDA-MB-231 cell lines
}

\author{
Meltem Uçar ${ }^{1^{*}}$, Orhan Değer ${ }^{2}$ \\ ${ }^{1}$ Faculty of Health Science, European University of Lefke, Lefke, Northern Cyprus, TR-10 Mersin, ${ }^{2}$ Department of Medical \\ Biochemistry, Faculty of Medicine, Karadeniz Technical University, Trabzon, Turkey
}

*For correspondence: Email: mucar@eul.edu.tr; Tel: +90 393660 2000-2567

Sent for review: 27 December 2018

Revised accepted: 20 January 2019

\begin{abstract}
Purpose: To investigate the effect of Dulbecco's Modified Eagle Medium (DMEM) extract of Turkish propolis on proliferation, cytotoxicity and lateral motility in MDA-MB-231 cells.

Methods: The antiproliferative activity of DMEM extracts of propolis was determined colorimetrically in MDA-MB-231 cells using 3-[4,5-dimethylthiazol-2-yl]-2,5-diphenyltetrazolium bromide (MTT) assay. Cell toxicity and wound healing effects of the prpolis extracts were determined with trypan blue exclusion assay and wound-healing assay, respectively.

Results: The cell number of MDA-MB-231 cells were decreased by the extracts at all concentrations for $72 \mathrm{~h}$. The highest antiproliferative activity of the extract was demonstrated at $10 \mathrm{mg} / \mathrm{mL}$ for $24-72 \mathrm{~h}$. Moreover, 5 and $0.31 \mathrm{mg} / \mathrm{mL}$ of the propolis extract showed significant antiproliferative activity at $72 \mathrm{~h}$ of incubation. The extract showed cytotoxic effect to MDA-MB-231 cells at $10 \mathrm{mg} / \mathrm{mL}$. The extract (at a dose of $2.5 \mathrm{mg} / \mathrm{mL}$ ) during 24 - $72 \mathrm{~h}$ did not produce any effect on lateral motility in MDA-MB-231 cells in the wound healing assay.

Conclusion: These results indicate that the DMEM extract of propolis exerts antiproliferative and cytotoxic effects on MDA-MB-231 cells at different concentrations.
\end{abstract}

Keywords: Propolis, Proliferation, Cytotoxicity, Motility, Breast cancer

\begin{abstract}
This is an Open Access article that uses a funding model which does not charge readers or their institutions for access and distributed under the terms of the Creative Commons Attribution License (http://creativecommons.org/licenses/by/4.0) and the Budapest Open Access Initiative (http://www.budapestopenaccessinitiative.org/read), which permit unrestricted use, distribution, and reproduction in any medium, provided the original work is properly credited.

Tropical Journal of Pharmaceutical Research is indexed by Science Citation Index (SciSearch), Scopus, International Pharmaceutical Abstract, Chemical Abstracts, Embase, Index Copernicus, EBSCO, African Index Medicus, JournalSeek, Journal Citation Reports/Science Edition, Directory of Open Access Journals (DOAJ), African Journal Online, Bioline International, Open-J-Gate and Pharmacy Abstracts
\end{abstract}

\section{INTRODUCTION}

Each year, more than 14.1 million people are diagnosed with cancer and most of them live in low and middle income countries [1]. The most common cancer type among woman in the United States between 1975 and 2014 was breast cancer [2]. Recently, researchers have investigated chemotherapeutic or complementary roles of natural compounds in the treatment of cancer $[3,4]$. Propolis is collected from gummy plants and trees by bees (Apis Mellifera) for repairing splits in their hive, and defending the hive from invaders and diseases. Propolis has been applied in folk medicine and apitherapy for centuries due to its pharmaceutical and biological properties such as immunododulatory, wound healing, antitumoral, antimicrobial and antioxidant activities [5,6].

The major constituents of propolis are flavonoids, phenolic acids and their esters (about $50 \%$ ); 
fatty acids and waxes (about $30 \%$ ); and essential and aromatic oils, pollen and other organic substances and minerals making up 20 $\%$, with composition influenced by factors such as geographic area, climate and type of plants and trees that bees tap from $[7,8]$. Turkish propolis is rich from in flavonoids and phenolics such as naringenin, quercetin, pinocembrin, caffeic acid, apigenin, caffeic acid phenyl ester, pinobanksin, galangin, chrysin and cinnamic acids $[9,10]$. Studies have shown that many biological activities of propolis including antitumor activity may be related to its flavonoid and phenolic acid compositions [11-14]. Ethanol, methanol, water, dimethyl sulfoxide (DMSO), polyethylene glycol (PEG), oil, hexane and ethyl acetate have been used as solvents for extraction of propolis [14-16]. The present study is the first to use DMEM as a solvent for extracting propolis.

The aim of this study was to investigate the antiproliferative, cytotoxic and lateral motility effects of DMEM extracts of Turkish propolis on MDA-MB-231 cells.

\section{EXPERIMENTAL}

\section{Chemicals}

L-glutamine-containing DMEM, DMEM without glutamine, glucose and phenol red, FBS, penicillin-streptomycin, MTT, trypan blue, DMSO, glycine, trypsin, ethylenediaminetetraacetic acid (EDTA) and $\mathrm{NaCl}$ were supplied by Sigma (United Kingdom).

\section{Preparation of DMEM extract of Turkish propolis}

Propolis samples were collected from Trabzon in Turkey (Fanus Food Company, Trabzon). Five gram of the sample was ground and kept at -20 ${ }^{\circ} \mathrm{C}$. The ground propolis sample was dissolved in $20 \mathrm{~mL}$ of DMEM without glucose, glutamine or phenol red, by continuous shaking at $150 \mathrm{rpm}$ in a $60{ }^{\circ} \mathrm{C}$ water bath for $24 \mathrm{~h}$. The extract was centrifuged for $10 \mathrm{~min}$ at $4000 \mathrm{rpm}$, and then subjected to microfiltration and sterilisation to obtain a stock solution of concentration 250 $\mathrm{mg} / \mathrm{mL}$ which was kept away from light at $4{ }^{\circ} \mathrm{C}$. Various concentrations of working solutions (10, $5,2.5,1.25,0.63,0.31$ and $0.16 \mathrm{mg} / \mathrm{mL}$ ) were prepared by diluting the stock of $250 \mathrm{mg} / \mathrm{mL}$ with DMEM.

\section{Cell culture}

MDA-MB-231 breast cancer cells were purchased from American Type Culture
Collection (ATCC, USA). The cells were maintained in DMEM containing $4 \mathrm{mM} \mathrm{L-}$ glutamine and $5 \% \mathrm{FBS}$, and incubated at $37{ }^{\circ} \mathrm{C}$ in a $100 \%$ humidity atmosphere with $5 \% \mathrm{CO}_{2}$, The cancer cells were passaged every 3 - 4 days with a solution containing trypsin $(0.25 \%)$ and EDTA (0.02 \%) [17].

\section{Cell viability assay}

Cell viability of MD-MB-231 cells was assayed using trypan blue exclusion following incubation for 24, 48 and $72 \mathrm{~h}$ with normal growth medium DMEM, and propolis extract at doses of 1.25 , $2.5,5.0$, and $10.0 \mathrm{mg} / \mathrm{mL}$. The number of dead and live cells was assessed microscopically from 30 fields of view randomly selected for that purpose [18]. The results were obtained from 3 separate experiments.

\section{MTT cytotoxicity assay}

The MDA-MB-231 cells were seeded overnight into 24-well plates at a density of $1.5 \times 10^{4}$ cells /well. Proliferation of MDA-MB-231 cells were determined colorimetrically using MTT assay [19].

\section{Wound healing assay}

Lateral motility was determined with wound healing assay in the MDA-MB-231 cells with and without treatment with DMEM extract of propolis. A marker pen was used to draw parallel lines on the reverse side of empty $35 \mathrm{~mm}$ petri dishes. The cells were seeded at $5 \times 10^{4}$ cells in $35 \mathrm{~mm}$ petri dishes and subjected to incubation for $24 \mathrm{~h}$ at $37{ }^{\circ} \mathrm{C}$. The cultured cells were scratched with a $200-\mu l$ tip and washed 4 times with culture media DMEM. Then, they were treated with and without $2.5 \mathrm{mg} / \mathrm{mL}$ DMEM extract of propolis for 24, 48 and 72 h. The space from scratch treatment between control and treated culture cells were quantified by using inverted microscope appearance (ID 03 Carl Zeiss Ltd, Welwyn Garden City, UK). Wound healing assays were repeated four times [20].

\section{Statistical analysis}

Cell viability and MTT assays were repeated thrice, while wound healing assay was repeated four separate times to ensure accurate results. All results are expressed as mean \pm standard error of the mean (SEM). Student's $t$-test was used for comparing the effect of DMEM extracts of propolis on MDA-MB-231 cells and control (SPSS 20.0, IBM, Armonk, NY, United States of America).Values of $p<0.05$ were taken as indicative of statistical significance of differences. 


\section{RESULTS}

DMEM extract of Turkish propolis showed anti proliferative effect relative to control cells in $72 \mathrm{~h}$ at all concentration of 0.16 up to $10 \mathrm{mg} / \mathrm{mL}$. The extract significantly decreased cell number of MDA-MB-231 cells at doses 10, 5, and 0.31 $\mathrm{mg} / \mathrm{mL}$, as shown in Figure 1 . In addition, the results of trypan blue assay were verified with MTT results. All data are shown at Table 1 . The DMEM extract of propolis at a dose of $10 \mathrm{mg} / \mathrm{mL}$ showed cytotoxic effect on MDA MB 231 cells. However, at a dose of $5 \mathrm{mg} / \mathrm{mL}$, the DMEM extract of propolis did not show cytotoxic effect, although it produced some morphological changes in MDA MB 231 cells (results not presented). Arising from the results of the MTT and cell viability assays, $2.5 \mathrm{mg} / \mathrm{mL}$.

DMEM extract of propolis was chosen for investigating the wound healing effects of extracts on MDA-MB-231 cells. It was revealed that $2.5 \mathrm{mg} / \mathrm{mL}$ DMEM extracts of propolis did not significantly change wound healing effect in MDA-MB-231 cells, when compared to cells in the control group. The results of wound healing effects of DMEM extracts of propolis are shown in Table 2.

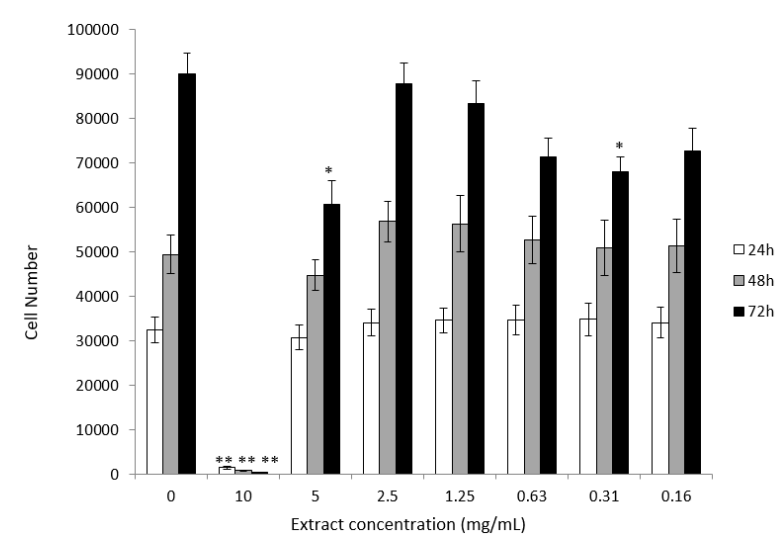

Figure 1: Mean cell number of MDA-MB-231 cells incubated with DMEM extracts of propolis and control MDA-MB-231 cells for 24, 48 and 72 h. Data are presented as mean \pm SEM, $\mathrm{n}=3 ;{ }^{*} p<0.05$, ${ }^{\star *} p<$ 0.01

Table 1: Cell viability of MDA-MB-231 cells incubated with different concentrations of DMEM extract of propolis $(10,5,2.5,1.25 \mathrm{mg} / \mathrm{mL})$ for 24,48 and $72 \mathrm{~h}$

\begin{tabular}{lccccc}
\hline \multirow{2}{*}{ Time $(\mathbf{h})$} & \multicolumn{5}{c}{ Concentration of DMEM extract of propolis $(\mathbf{m g} / \mathbf{m L})$} \\
\cline { 2 - 6 } & $\mathbf{0}$ & $\mathbf{1 . 2 5}$ & $\mathbf{2 . 5}$ & $\mathbf{5}$ & $\mathbf{1 0}$ \\
\hline $\mathbf{2 4}$ & $99.20 \pm 0.15$ & $99.59 \pm 0.20$ & $99.66 \pm 0.09$ & $99.96 \pm 0.02$ & $98.69 \pm 0.76$ \\
$\mathbf{4 8}$ & $99.00 \pm 0.36$ & $99.57 \pm 0.11$ & $99.63 \pm 0.15$ & $99.15 \pm 0.38$ & $82.75 \pm 12.91$ \\
$\mathbf{7 2}$ & $98.29 \pm 0.44$ & $98.38 \pm 0.46$ & $99.03 \pm 0.41$ & $97.86 \pm 0.57$ & $70.04 \pm 13.84$ \\
\hline \multicolumn{4}{l}{ Values are mean \pm SEM $(\mathrm{n}=3)$}
\end{tabular}

Table 2: Motility index of control MDA-MB-231 cells incubated with $2.5 \mathrm{mg} / \mathrm{mL}$ of DMEM extract of propolis

\begin{tabular}{lcc}
\hline Time (h) & $\begin{array}{c}\text { MI of Control } \\
\text { MDA-MB-231 } \\
\text { cells }( \pm \text { SEM) }\end{array}$ & $\begin{array}{c}\text { MI of treated MDA- } \\
\text { MB-231 cells } \\
\text { ( } \pm \text { SEM) }\end{array}$ \\
\hline $\mathbf{2 4}$ & $0,34 \pm 0.03$ & $0.41 \pm 0.02$ \\
$\mathbf{4 8}$ & $0.57 \pm 0.04$ & $0.68 \pm 0.03$ \\
$\mathbf{7 2}$ & $0.82 \pm 0.05$ & $0.90 \pm 0.03$ \\
\hline
\end{tabular}

\section{DISCUSSION}

This study is the first to use DMEM as a solvent for extraction of propolis. In the literature, ethanol is usually used for preparation of extracts of propolis. Extracts of propolis made with DMSO were used at $\mu \mathrm{g} / \mathrm{mL}$ concentration because of the toxic effect of the solvent [13,21-23]. Higher concentrations of DMEM propolis extract or extracts prepared with other cell culture media can be used in cell culture experiments. In previous studies, it was determined that DMSO extracts of Turkish propolis contained naringenin, galangin, chrysin, quercetin, kaempferol and cinnamic acid derivatives, while water extracts of Turkish propolis contained caffeic and caffeoyl quinic acids, as revealed by HPLC analysis [24]. Flavonoid and phenolic compounds of DMEM extracts of propolis should be investigated for effects of propolis extract were seen at microgram levels.

The DMEM extract of propolis showed cytotoxic effects at milligram levels. Thus, $10 \mathrm{mg} / \mathrm{mL}$ of the extract of propolis showed strongly antiproliferative and cytotoxic effects in MDA-MB231 cells. However, $2.5 \mathrm{mg} / \mathrm{mL}$ DMEM extracts of propolis did not show delayed effect on invasion in MDA-MB-231 cells. The DMEM extract of propolis may be used for further investigations and may be an alternative extract for antiproliferative, cytotoxic and antimetastatic investigations with cancer cells. supporting data. In many studies, the cytotoxic

Values are mean \pm SEM $(n=3)$ 


\section{CONCLUSION}

The findings of the present study show that DMEM extracts of Turkish propolis have antiproliferative and cytotoxic effects, but at a dose of $2.5 \mathrm{mg} / \mathrm{mL}$, it does not exert a wound healing effect on MDA MB 231 cells. Thus, DMEM extract of propolis may be a suitable alternative apitherapy extract for cancer research.

\section{DECLARATIONS}

\section{Acknowledgement}

This work was supported by Prof Dr Mustafa Bilgin Ali Djamgoz from Imperial College in London, UK, and Karadeniz Technical University and European University of Lefke, Northern Cyprus, Turkey.

\section{Conflict of Interest}

No conflict of interest associated with this work.

\section{Contribution of Authors}

The authors declare that this work was done by the authors named in this article and all liabilities pertaining to claims relating to the content of this article will be borne by them.

\section{REFERENCES}

1. Ferlay J, Soerjomataram I, Dikshit R, Eser S, Mathers C, Rebelo M, Parkin DM, Forman D, Bray F. Cancer incidence and mortality worldwide: Sources, methods and major patterns in GLOBOCAN 2012. Int J Cancer 2015; 136: E359-E386.

2. Siegel RL, Miller KD, Jemal A. Cancer statistics, 2018. CA Cancer J Clin 2018; 68: 7-30.

3. Rajagopal C, Lankadasari MB, Aranjani JM, Harikumar $K B$. Targeting oncogenic transcription factors by polyphenols: A novel approach for cancer therapy. Pharmacol Res 2018; 130: 273-291.

4. Rzepecka-Stojko A, Kabała-Dzik A, Moździerz A, Kubina $R$, Wojtyczka RD, Stojko R, Dziedzic A, JastrzębskaStojko Z, Jurzak M, Buszman E, Stojko J. Caffeic acid phenethyl ester and ethanol extract of propolis induce the complementary cytotoxic effect on triple-negative breast cancer cell lines. Molecules 2015; 20: 9242-9262.

5. Oryan A, Alemzadeh E, Moshiri A. Potential role of propolis in wound healing: Biological propoerties and therapeutic activities. Biomed Pharmacother 2018; 98 : 469-483.

6. Sforcin JM, BankovaV. Propolis: Is there a potential for the development of new drugs? J Ethnopharmacol 2011; 133: 253-260.
7. Greenaway W, May J, Scaysbrook T, Whatley FR. Identification by gas chromatography-mass spectrometry of 150 compounds in propolis, Zeitschrift fur Naturforschung C, 1990; 46: 111-121.

8. Sales A, Alvarez A, Areal MR., Maldonado L, Marchisio $P$, Rodriguez M., Bedascarrasbure $E$. The effect of different propolis harvest methods on its lead contents determined by ET AAS and UV-visS, J Hazard Mater 2006; 137: 1352-1356.

9. Guzelmeric E, Ristivojevic $P$, Trifkovic J, Dastan $T$, Yilmaz O, Cengiz O, Yesilada E. 2018. Authentication of Turkish propolis through HPTLC fingerprints combined with multivariate analysis and palynological data and their comparative antioxidant activity. LWT - FOOD SCI TECHNOL, 2018; 87: 23-32.

10. Uzela A, Sorkun K, Onçağ O, Cogulu D, Gençay O, Salih $B$. Chemical compositions and antimicrobial activities of four different Anatolian propolis samples. Microbiol Res 2005; 160: 189-195.

11. Frozza CODS, Santos DA, Rufatto LC, Minetto L, Scariot FJ, Echeverrigaray S, Pich CT, Moura S, Padilha FF, Borsuk $S$, et al. Antitumor activity of Brazilian red propolis fractions against Hep-2 cancer cell line. Biomed Pharmacother 2017; 91: 951-963.

12. de Mendonça IC, Porto IC, do Nascimento TG, de Souza NS, Oliveira JM, Arruda RE, Mousinho KC, dos Santos $A F$, Basílio-Júnior ID, Parolia $A$, et al. Brazilian red propolis: phytochemical screening, antioxidant activity and effect against cancer cells. BMC Complement Altern Med 2015; 15: 357(1-12).

13. Turan I, Demir S, Misir S, Kilinc K, Mentese A, Aliyazicioglu Y, Deger O. Cytotoxic Effect of Turkish Propolis on Liver, Colon, Breast, Cervix and Prostate Cancer Cell Lines. Trop J Pharm Res 2015; 14: 777 782.

14. Burdock GA. Review of the biological properties and toxicity of bee propolis (propolis). 1998. Food Chem Toxicol 1998, 36: 347-363.

15. Trusheva B, Trunkova D, Bankova V. Different extraction methods of biologically active components from propolis: a preliminary study, Chem Cent $J$ 2007; 1: 13(1-4).

16. Kubiliene L, Laugaliene V, Pavilonis A, Maruska A, Majiene $D$, Barcauskaite $K$, Kubilius $R$, Kasparaviciene G, Savickas A. Alternative preparation of propolis extracts: comparison of their composition and biological activities. BMC Complement Altern Med 2015; 15:156(17).

17. Fraser SP, Diss JK, Chioni AM, Mycielska ME, Pan $H$, Yamaci RF, Pani F, Siwy Z, Krasowska M, Grzywna Z, et al. Voltage-gated sodium channel expression and potentiation of human breast cancer metastasis, Clin Cancer Res 2005; 11: 5381-5389.

18. Fraser SP, Diss JKJ, Lloyd LJ, Pani F, Chioni AM, George AJT, Djamgoz MBA. T-lymphocyte invasiveness: control by voltage-gated $\mathrm{Na}+$ channel activity, FEBS Letters 2004; 569: 191-194. 
19. Chioni AM, Shao D, Grose R, Djamgoz MBA. Protein kinase $A$ and regulation of neonatal Nav1.5 expression in human breast cancer cells: Activity-dependent positive feedback and cellular migration. Int $J$ Biochem Cell Biol 2010; 42: 346-358

20. Wang $B$, Xing $Z$, Wang $F$, Yuan $X$, Zhang $Y$. Fangchinoline inhibits migration and causes apoptosis of human breast cancer MDA-MB-231 cells. Oncol Lett 2017; 14: 5307-5312.

21. Silva-Carvalho R, Miranda-Gonçalves V., Ferreira AM, Cardoso SM, Sobral AJFN, Almeida-Aguiar C, Baltazar F. Antitumoural and antiangiogenic activity of Portuguese propolis in in vitro and in vivo models. $J$ Funct Foods 2014; 11: 160-171.
22. Premratanachai $P$, Chanchao $C$. Review of the anticancer activities of bee products, Asian Pac J Trop Biomed 2014; 4: 337-344.

23. Sulaiman GM, Ad'hiah AH, Al-Sammarrae KW, Bagnati $R$, Frapolli $R$, Bello $E$, Uboldi $S$, Romano M, Panini N, Scanziani $E$, et al. Assessing the anti-tumor properties of Iraqi propolis in vitro and in vivo. Food Chem Toxicol 2012; 50: 1632-1641.

24. Cakiroglu TN. Investigation of solubility of Turkish Propolis in different solvents. Master Thesis, Karadeniz Technical University, Institute of Health Sciences, Trabzon, Turkey 2010. 